Monika Wiśniewska-Kin

ORCID: 0000-0002-6300-8435

Uniwersytet Łódzki

mkin@eczgierz.pl

\title{
„Momenty wychowawcze" w projektowaniu procesu kształcenia kulturowej kompetencji dzieci
}

\section{Summary}

"Educational moments" in designing the process of developing cultural competence

The article presents the results of an educational research project implemented in the school year 2018/2019 in selected primary schools in urban environment (Łódź). The aim of the study was to diagnose Janusz Korczak's “educational moments" in designing the process of developing cultural competence. The investigator appeared in the role participant as an observer (the researcher came from the examined environment and had the opportunity to "blend into" the events). The material came from participant observation. The observation embraced practical and socio-cognitive activity of the pupils. The results allow recognition in how a child, applying language, marks its being in the world, how it acts via language, how it uses language to reach the mysteries of the world and what it does with language during this operation. The final comment suggests that school is there to help a child to interpret the world, to recognize various phenomena, to assume attitudes towards them, and to make their independent evaluation.

Keywords: concept of Janusz Korczak, “educational moments”, project of language education, cultural competence

Słowa kluczowe: koncepcja Janusz Korczaka, „momenty wychowawcze”, projekt kształcenia językowego, kulturowa kompetencja

Ideę przewodnią, uruchamiającą refleksję nad projektowaniem procesu kształcenia kulturowej kompetencji (Kłakówna 2003) dzieci z perspektywy Korczakowskiej aksjologii, dostrzegam w kategorii „momentów wychowawczych” (Korczak 2017). Wyprowadzona $\mathrm{z}$ nauki o rozpoznawaniu (obecnie uprawianej $\mathrm{w}$ ramach paradygmatu interpretatywno-konstruktywistycznego) umożliwia zrekonstruowanie objawu intelektualnego - ucznia czy zespołu (Korczak 2017: 10-11). Korczak jako wybitny prekursor konstruktywizmu zainicjował tą kategorią refleksję teoretyczną wprowadzającą wyłom w myśleniu o zanurzonym $w$ kontekst kulturowy procesie dziecięcego uczenia się. To, jak dziecko rozumie rzeczywistość i kim się w niej staje, zależy bowiem nie tylko bezpośrednio od „gotowości" umysłowej i indywidualnego wysiłku intelektualnego, ale również od doświadczanych sposobów rozumienia otaczającej rzeczywistości. Posługując się wyjątkowo 
trafną metaforą UMYSŁ DZIECKA to LAS, Korczak wydobywa istotę upośrednionego uczenia się: „Umysł dziecka to las, którego wierzchołki lekko się poruszają, gałęzie splatają, liście drżąc dotykają. Są chwile, gdy drzewo łączy się delikatnym dotknięciem z sąsiednim, a przez sąsiada udziela mu się drganie stu, tysiąca drzew - całego lasu. Każde nasze: »dobrze - źle - uważaj - jeszcze raz « - to jest wicher, który chaos wprowadza" (Korczak 2017: 83-84). Sformułowane założenie o interakcyjnej orientacji w konstruowaniu znaczeń zawiera praktyczną dyrektywę: w procesie poznawania świata dziecko najpierw powinno doświadczać aktywnych działan (,poruszeń”, „dotknięć”, „drgań”) ukierunkowanych na rozwiązywanie problemów w obecności innych i stopniowo, w wyniku podzielania pewnych czynności rozwiązywać problemy samodzielnie. W procesie intersubiektywnego uczenia się przez podzielanie osobistych znaczeń ważne jest też to, że wzajemne uczenie się od kogoś i przy pomocy kogoś, ma charakter kulturowy, wspierający, a nie schematyzujący, indoktrynujący. Korczak przestrzega bowiem przed dominującą rolą dorosłego pośrednika: „Rzadko kiedy nauczyciel nie doda czegoś do prawidłowej odpowiedzi ucznia. »Prędzej - wolniej - głośniej - jeszcze raz - dobrze - dalej«. (...) Niestety! - i »prędzej«, i »wolniej« zawodzą, demoralizują dzieci - zawisają w powietrzu" (Korczak 2017: 16-17). W wyniku takich praktyk uczniowie zostają zawieszeni pomiędzy „okropnym, monotonnym, bezmyślnym, żebraczym tonem szkolnego opowiadania" (Korczak 2017: 83) a spontanicznym i zróżnicowanym charakterem codziennej komunikacji. Dyskurs szkolny, profilując charakter odbioru rzeczywistości, nie powinien się zatem sprowadzać do mówienia o świecie danym, niejako gotowym i skończonym. Zamknięty w klatce schematów, usztywnień, stereotypów, nauczyciel „nie tylko zmusza, ale i sam musi, męcząc, sam się męczy" (Korczak 2017: 20-21). Traci zatem możliwość pośredniego wpływania na bieg procesu dojrzewania dziecięcej aktywności poznawczo-interpretacyjnej, „bo nie umie czytać między wierszami ich od niechcenia rzucanych zdań. Chce, żeby się dziecko zwierzało ze wszystkich myśli i uczuć. Sam niezbyt skłonny do zwierzeń, nie chce czy nie umie zrozumieć, że dziecko jest o wiele bardziej wstydliwsze, drażliwsze, czulsze [niż nauczyciel] na brutalne śledzenie jego duchowych drgnień" (Korczak 2017: 87-88).

Jeszcze raz podkreślę: za inicjowanie środowiska stymulującego rozwijanie i wzbogacanie wielorakich kompetencji dzieci oraz rozszerzanie pola znaczeniowego dziecięcych pojęć odpowiada „umiejąca czytać między wierszami i rozpoznawać duchowe drgania” druga osoba. W poczuciu odpowiedzialności, nie podszytej strachem, lecz zasadzonej na wyobraźni i wrażliwości, dba o mądre bycie wśród innych. Tak rozumiana odpowiedzialność nie potrzebuje regulaminów, nakazów, lecz jedynie woli, świadomej decyzji o mądrym budowaniu JA w relacji do TY i INNI: „każde słowo znajduje echo w stu umysłach, każdy czyn śledzi sto par czujnych oczu; jeśli uda się wzruszyć, przekonać, pobudzić do czynu, to umiłowanie, wiara, czyn - potężnieje w sto; zawsze, nawet wówczas, gdy zawiodą wszystkie nieomal dzieci, jedno czy dwoje - nie dziś, to jutro - przekona, że zrozumiało, odczuło, jest ze mną" (Korczak 2017: 51). Wychowanie powinno więc być inspirowaniem do odpowiedzialności, współtworzeniem, współmyśleniem i współodkrywaniem 
wartości przez wychowawcę i wychowanka. Jesteśmy zatem odpowiedzialni nie tylko za to, co zrobiliśmy, ale również za to, jacy są nasi uczniowie (tzn. za normy i postawy, które określają ich zachowania), gdyż to, jacy są teraz, określa w dużej mierze ich przyszłość.

Nieco inną kwestią jest dynamiczny zakres poczucia odpowiedzialności, który zmienia się zależnie od kontekstu doświadczenia. Faktyczna odpowiedzialność jest zakotwiczona w konkretnej, zmiennej, często niepowtarzalnej sytuacji. Szczególnego znaczenia nabiera pytanie o sposoby rozwijania tej dyspozycji. Aby wychowanie prowadziło ku odpowiedzialności, powinno się opierać na kilku elementarnych założeniach (Korczak 2012):

- wychowanie powinno być oparte na indywidualności, szacunku wobec niepowtarzalności każdej jednostki;

- podmiotowość rodzi odpowiedzialność, a odpowiedzialność jest warunkiem podmiotowości;

- tylko autonomia połączona z samowiedzą prowadzącą do samowychowania i samorozwoju zapewni autentyczne poczucie odpowiedzialności.

Nowe spojrzenie na proces odpowiedzialnego bycia wśród innych wzbogaciło się o jeszcze jeden aspekt. W rozumieniu Korczaka sprawą dużej wagi jest organizowanie sytuacji edukacyjnych o charakterze narracyjnym, w których uczniowie mogą używać naturalnych predyspozycji poznawczych i samodzielnie poszukiwać znaczeń, „rozmowa szybko i naturalnie zbliża cię z dzieckiem" (Korczak 2017: 54). Wraz z opanowaniem mowy dla dziecka rozpoczyna się przede wszystkim proces usensowniania, uświadamiania sobie otaczającej rzeczywistości i nadawania jej znaczeń: „tak trudno porozumieć się nam z dziećmi, a one używając tych samych co i my wyrazów, wkładają w nie zupełnie inną treść" (Korczak 2017: 76). Żywe narracje, czyli ustne historie z życia, stając się ,świętymi rozmowami uczuć, których nie ma prawa dotykać nauka” (Korczak 2017: 32-33), przekazują wielorakie znaczenia i żadnej opowieści nie można zamknąć w granicach jednego horyzontu, każdą bowiem opowieść, każde „misterium dźwięków, tonów zwiewnych, srebrnych” (Korczak 2017: 32-33) można „czytać” na wiele sposobów. Dla tak nieoczywistej i skomplikowanej sytuacji konieczne jest stworzenie warunków, w których taka rozmowa wyrasta i dojrzewa.

\section{$\mathrm{Z}$ inspiracji Korczakowską strategią projektowania „momentów wychowawczych”}

Jeśli zatem narracja staje się kluczowym narzędziem kultury, sprzyjającym konstruowaniu modeli własnej tożsamości, zarówno osobistej, jak i społecznej, oraz odnajdywaniu swojego miejsca w uwspólnionej sieci społecznych relacji (Bruner 2006), to pozostaje rozważyć, w jaki sposób zaprojektować zdarzenia edukacyjne, aby rozbudzały: wrażliwość narracyjną, poznawczą motywację, gotowość stawiania niekonwencjonalnych pytań i nieschematycznych rozwiązań.

W podjętej próbie zrekonstruowania zewnętrznych warunków wyzwalających dziecięcą aktywność w procesie uczenia się oraz poczucie odpowiedzialności za wykonanie 
zadania odwołałam się do strategii badań jakościowych. Jakościowe podejście pozwala uchwycić dziecięce poznanie jako „«ciąg perspektyw», ujmujących rzeczywistość tak, jak ujmuje się pejzaż, którego - choć istnieje niezależnie - nie sposób spostrzec inaczej jak tylko z różnych punktów widzenia" (Hołówka 1986: 119). Interesowały mnie dziecięce strategie poznawcze (sposób postrzegania, czyli zdobywania danych, oraz sposób myślenia, czyli ich przetwarzania), a także wytwory procesu poznawczego (językowy obraz wspólnoty) (Maćkiewicz 2000: 107-108). Język pojmowany antropologicznie jako część działalności człowieka - zarówno mentalnej, jak i społecznej - ujawnia w badaniach dyskursu prowadzonego przez dzieci niepowtarzalność ich osobowości, spontaniczność reakcji, oryginalność ujmowania rzeczywistości, słowem - wszystko to, co określa ich podmiotowość. Dyskurs dziecięcy, wiążąc użycie języka z procesem nadawania znaczeń, stużyt emancypacji. Walor wyzwalajacy uobecniat się w procesie wrastania w język $i$ czynienia zeń narzędzia społecznej komunikacji. Przyznanie dziecku prawa do używania własnego języka w procesie oswajania świata jest rezultatem głębokiej reorientacji w pojmowaniu roli języka w procesie rozwoju osobniczego.

Analizie poddałam zarówno konceptualizacje jednostkowe, jak i typowe dla subkultury dziecięcej i kultury szkoły. Takie ujęcie obrazu świata wyprofilowanego w różnorodnych wypowiedziach uczniowskich miało umożliwić opisanie ewolucji znaczenia: od potocznej bazy kognitywnej, poprzez reinterpretację naukową (szkolną), do własnego, oryginalnego ujęcia. Wiedza jest bowiem „niegotowa”, co oznacza, że nie istnieje ostateczny sens pojęcia. Badacza musi więc interesować nie tylko to, co poznawane, ale również rekonstrukcja drogi myślowej dziecka, jego zdolności poznawczych, które ujawniają się podczas thumaczenia pojęcia „wspólnota”.

$\mathrm{Z}$ namysłu nad językowym obrazem uczniów, wyzwalanym w warunkach pobudzającego rozwój środowiska edukacyjnego, wyprowadziłam cele badawcze. Głównym celem badań uczyniłam zrekonstruowanie zainicjowanych narracji uczniowskich. Dziecięcy namysł skupiał się wokół obszaru wspólnotowego, uszczegółowionego i wyartykułowanego w wybranych tematach problemach: 1. Potrzeba - wymiary - warunki wspólnego bycia razem; 2. Strategie zawiązywania wspólnoty i możliwości jej scalania; 3 . Wspólnota poddawana próbie.

Materiał do badań zapewniły zajęcia edukacyjne, które organizowałam w ramach obserwacji uczestniczącej ${ }^{1}$. Występując $\mathrm{w}$ roli interpretacyjnie zaangażowanego obserwatora-jako-uczestnika (Angrosino 2010) swoje uczestnictwo pojmowałam jako sensowną obecność (Piekarski 2017). W badaniach wykorzystałam zbiorowe i indywidualne formy pracy z dziećmi, dzięki którym mogłam objąć obserwacją czynności uczniów, a także skutki tych czynności (przede wszystkim werbalne reprezentacje i plastyczne konkretyzacje). Badania przeprowadziłam z uczniami trzech klas trzecich (łącznie 76 uczniów) szkół

1 W dwuletnim gromadzenia materiału badawczego uczestniczyły trzy seminarzystki: J. Kotynia, E. Kowalska, K. Krawczyk. Cały etap gromadzenia danych zamknął się w dwóch latach (w roku akademickim 2016/2017 i 2017/2018) 
podstawowych zlokalizowanych $\mathrm{w}$ środowisku wielkomiejskim ${ }^{2}$. Zdecydowałam się na wybór trzecioklasistów ze względu na dobrze rozwinięte kompetencje językowe i komunikacyjne, które ułatwiają eksplikację myśli.

Przestrzeń do rozmowy z dziećmi o tych wymiarach wspólnoty stworzyła książka obrazkowa (picture book) Iwony Chmielewskiej Pamiętnik Blumki. Wybór tego tekstu wynikał z głębokiego przeświadczenia o roli, jaką może on odegrać w formatywnym wymiarze edukacji wczesnoszkolnej. Przy czym - co warte podkreślenia - literatura ta nie tylko godzi zobowiązania etyczne $\mathrm{z}$ wysokim poziomem artystycznym, ale także uwzględnia psychologiczne aspekty odbioru.

\section{Proces rekonstruowania dziecięcych „objawów intelektualnych”}

1. Projekt cyklu zajęć uwzględniał aktywność uczniów w procesie uczenia się i ich poczucie odpowiedzialności za wykonanie zadania. Uczniowie używali różnych procedur badawczych w procesie rozwiązywania problemu, podejmowali próby bez obawy o błędy, mieli czas na sformułowanie odpowiedzi.

N: Odczytujemy tekst Pamiętnik Blumki Iwony Chmielewskiej i uruchamiamy namysł dzieci o członkach wspólnoty z Domu Sierot. Kto mieszkał w Domu Sierot. Spróbujcie stworzyć portrety psychologiczne wszystkich domowników (dwanaściorga dzieci i dwojga dorosłych).

U: Pan Doktor i Pani Stefa byli dobrymi ludźmi. Sprawiedliwie wychowywali dzieci, rozumieli i wspierali je. Dzieci były bardzo różne: miłe i sympatyczne jak Blumka, wesołe i wysportowane jak Ryfka, zdolne i pracowite jak Zygmuś, Abramek, Reginka, Aron i Kocyk, niegrzeczne i źle się zachowujące, ale też pracujące nad swoim zachowaniem jak Hanna, Chaimek i Szymek. Uśmiechnięte jak Stasiek i smutne jak Aron, małe jak Kocyk i duże jak Stasiek.

$\mathrm{N}$ : Zastanówcie się, jak doszło do tego, że grupka przypadkowych dzieci, które nie wybrały się nawzajem (nie znały się wcześniej, nie miały wspólnych zainteresowań, nie były w tym samym wieku) pod opieką Doktora potrafiła stworzyć „zgrany” rozumiejący się zespół.

U: Ja myślę, że dlatego, że połączyła ich wspólna sytuacja, czyli to, że nie miały rodziców.

U: Miały podobne problemy, no i pewnie dlatego, że w takiej ,zgranej” gromadzie było im razem raźniej i czuły się bezpiecznie, mimo tego że była wojna.

N: Spróbujcie wyobrazić sobie innych członków tej wspólnoty, czy każde dziecko mogłoby tam zamieszkać? Jakich praw i zwyczajów musiałoby przestrzegać, jakimi cechami się odznaczać?

U: Nie każdy by tam pasował, tylko te dzieci, które zgodziłyby się przestrzegać ustalonych zasad.

U: Musiałyby być pracowite, bo te dzieci dużo pracowały.

\footnotetext{
2 Wybrane do badań szkoły publiczne to: Szkoła Podstawowa nr 83 im. St. Jachowicza w Łodzi; Szkoła Podstawowa nr 120 im. Konstytucji 3 Maja w Łodzi; Szkoła Podstawowa nr 199 im. J. Tuwima w Łodzi.
} 
U: I być sprawiedliwe, żeby mogły uczestniczyć w sądach.

U: I zacząć myśleć o innych, co można dać wspólnocie od siebie.

U: No i musiałyby szanować zwierzęta, bo tego uczył Doktor; i nie mogłyby chodzić zbyt późno spać.

U: A ja myślę, że każde dziecko potrzebujące pomocy, jak czegoś by nie umiało albo nie wiedziało, to Doktor by je nauczył.

Zainicjowana rozmowa o wspólnocie poddawanej próbie uświadomiła dzieciom, że doświadczenia i przygody będące udziałem grupy dwanaściorga dzieci pod opieką doktora Korczaka wprowadzają krąg problemów i elementarnych idei, jakimi powinna się kierować każda społeczność ludzka, jeśli jej życie ma być harmonijne, godne i pomyślne. Poddani próbom dzielności bohaterowie są zaradni i pomysłowi, wychodzą z nich pomyślnie, choć to przecież garstka osieroconych, bezbronnych dzieci pod opieką starszego pana.

2. Uczniowie wyposażeni w zaufanie do siebie nabrali przekonania, że w procesie rekonstruowania znaczeń ich osobiste sposoby objaśniania i interpretowania świata są uzasadnione.

N: Przypomnijcie, jakie rytuały (święta) wypracowali domownicy i w jakim celu je stworzyli.

U: Takim stałym zwyczajem były na przykład zebrania wszystkich dzieci i wychowawców w każdą sobotę, żeby porozmawiać o tym, co się wydarzyło przez cały tydzień; ciekawym zwyczajem było też pisanie skarg albo podziękowań na wspólnej tablicy; i Dzień Dobrych Uczynków, Dzień Pierwszego Śniegu; hałasowanie dla zabawy, zakładanie się z dziećmi; konkursy z nagrodami; czytanie na wieczór książek; odpoczywanie, żeby urosnąć.

N: Rozważcie teraz, w jaki sposób członkom wspólnoty Domu Sierot udało się przetrwać trudne chwile. Jakie cechy charakteru Doktora i postawy jego podopiecznych umożliwiły pokonanie trudności?

U: Doktor wierzył, że dzieci mogą się zmienić, i dawał im czas na zmianę.

U: Nie krzyczał na dzieci, tylko z nimi rozmawiał.

U: Wolał wymyślać nagrody, niż dawać kary, a dorosłych traktował tak jak dzieci, też można było poddać ich pod sąd.

U: Dzieci stosowały się do ustalonych zasad i słuchały Doktora; uczyły się od niego na przykład wybaczania, zaakceptowały Chaimka i Hannę.

N: A teraz porozmawiajmy o sytuacjach, w których najpełniej ujawniły się charakter i postawa Doktora. Które sytuacje były dla domowników sprawdzianem gotowości do sprostania trudnym zadaniom?

U: Sytuacja z Hanną, która wszystkich drapała, przezywała i nie chciała pracować, i przez to nikt się z nią nie chciał bawić. Pan Doktor jej do niczego nie zmuszał, tylko dużo z nią rozmawiał, ale tak, żeby inne dzieci nie słyszały, i Hanna się zmieniła.

U: Albo z Chaimkiem, którego musiał poddać pod sąd, żeby zrozumiał, że źle zrobił, ale potem przytulił go, pokazał, że nadal mu na nim zależy; nie chciał nikogo skrzywdzić i chciał wszystkich uszanować i czegoś dzieci nauczyć.

U: Ja podziwiam tego Doktora, że tak pokochał obce dzieci i że się nimi tak zajmował. 
W rozumieniu dzieci do utrzymania powiększającej się grupy nieodzowne są: pracowitość, zaradność, uczciwość, umiejętność współdziałania oraz poczucie odpowiedzialności. Dzieci dostrzegają, że kiedy sytuacja wychowanków staje się trudna, Doktor wraz z dziećmi biorą sprawy w swoje ręce: ze spokojem i wyrozumiałością przyjmują kłopoty Reginki, Hanny, Arona, Poli, Chaimka, nie odstępując od własnych przekonań i wcześniejszych decyzji. W trudnych sytuacjach opiekun nie czyni wymówek, przyjmuje obrót rzeczy ze spokojem i wyrozumiałością (,dużo rozmawia, ale tak, żebyśmy nie słyszeli”). Nie rezygnuje przy tym z własnych przekonań i decyzji, o których wie, że są słuszne (Chaimek za zniszczenie mrowiska staje przed dziecięcym sądem). Ujęci jego szlachetnością wychowankowie starają się sprostać wszystkim trudnościom, które zagrażają wspólnocie. Nie poddają się zwątpieniu, przygnębieniu, solidarnie współdziałają, wspierają się i usiłują znaleźć rozsądne wyjście. Dzieci odkrywają, że dzięki cechom charakteru wszystkich członków wspólnoty udaje się im przezwyciężyć trudności w stworzonym domostwie, w którym, tak jak w życiu, pojawiają się szczęśliwe sploty okoliczności oraz beznadziejne z pozoru tarapaty. Dzieci zauważyły też, że chociaż Doktora z wychowankami nie łączyły relacje rodzinne, udało się stworzyć zgrany, współpracujący ze sobą zespół. O jego powodzeniu zadecydowały umiejętności: współżycia we wspólnocie (życie bez wspólnoty jest niebezpieczne i często niesatysfakcjonujące) oraz współdziałania, która została wypracowana w zespole, czyli „zgrane” $i$,wypróbowane” bycie razem. Integralną częścią idei wspólnoty Doktora i wychowanków była „braterska powinność”, przejawiająca się gotowością do niesienia pomocy, współczuciem, solidarnością oraz ofiarnością wobec tych, którzy do niej należeli.

3. Nauczyciel, przygotowując uczniów do dokonywania samodzielnych odkryć, tworzy atmosferę wspierającą działania uczniów - angażuje ich w różne formy aktywności, a także stosuje system pozytywnych wzmocnień, udziela uczącym się informacji zwrotnych oraz próbuje wejść w ich sytuację.

N: Zaprojektujmy zasady postępowania dla różnych wspólnot poddawanych próbom (rodzinnej, rówieśniczej, w środowisku szkolnym i pozaszkolnym).

U: W grupie trzeba być wyrozumiałym, szanować się, pomagać sobie i się wspierać.

U: Wszyscy powinni mieć równe prawa i nikt nie powinien się czuć, jakby był gorszy.

U: Każdy powinien mieć czas dla siebie i na swoje zainteresowania.

U: Trzeba też pamiętać o swoich obowiązkach i być pracowitym.

U: Ważne jest też to, żeby być dobrym, bo dobro promieniuje na innych; głupio być złym wśród dobrych.

Działanie i obserwowanie jego rezultatów, a także podtrzymywanie uczniowskiego zorientowania na cel uruchomiły czynności o charakterze przekładu intersemiotycznego. Opracowanie utworu sprowadziliśmy do przygotowania kodeksu praw i obowiązków dzieci. Rozważania nad poczynaniami Starego Doktora i jego podopiecznych doprowadziły do konkluzji, że wspólnotę cementują przede wszystkim życzliwość, wyrozumia- 
łość, wzajemna opiekuńczość, zdolność wybaczania pomyłek, umiejętność dodawania otuchy w chwilach słabości, subtelnego wyczuwania potrzeb. Z lektury tekstu Pamiętnik Blumki uczniowie wyciągnęli wniosek, że warto być dobrym. Dobro - jak się okazuje silnie zespala wspólnotę, a o powodzeniu najtrudniejszych przedsięwzięć grupy w dużej mierze decyduje umiejętna pomoc. Dobro udziela się wtedy wszystkim, daje poczucie siły, pomaga pokonać strach, w kłopotliwej sytuacji stawia osoby niekierujące się dobrem.

4. Nauczyciel, ogniskując proces uczenia się wokół uczniowskich zainteresowań, dba również o przestrzeń do uruchomienia ich myślenia krytycznego.

N: A teraz porozmawiajmy o takich sytuacjach, które są dla Was sprawdzianem gotowości do sprostania trudnym zadaniom we wspólnocie.

U: Najgorsze są takie sytuacje, gdy z Facebooka dowiadujesz się, że ktoś z twoich znajomych ośmiesza cię.

U: Albo na grupie wypisuje rzeczy nieprawdziwe albo wyrzuca cię z grupy.

U: Ja uważam, że dzieci powinny mieć odwagę, żeby powiedzieć, co do kogoś mają, a nie chować się za Internetem.

U: Niektóre dzieci spotykają się tylko po to, żeby obgadywać inne osoby.

U: Teraz jest coraz więcej telefonów i gier komputerowych, trochę brakuje mi tego, że nie spotykamy się na piłkę.

U: To nie jest niestety tak jak w historii z tej książki. Dzieci tak łatwo sobie nie wybaczają, są bardziej złośliwe, nie cieszą się z tego, co dzieci z książki, mają od życia większe oczekiwania.

U: No i brakuje takich opiekunów jak Doktor. Dorośli nie mają dla nas czasu, nie rozmawiają z nami, nie traktują nas poważnie.

Historia dzieci z Domu Sierot pod opieką Starego Doktora stała się odniesieniem do tego, czego współcześnie doświadczają dzieci i z czym stykają się w realnym życiu, nie oferowała dzieciom naiwnych złudzeń. Wyjście poza krąg oczywistych i banalnych tematów wymagało uwzględnienia kilku warunków wstępnych podczas organizowania sytuacji edukacyjnych i przyjęcia zasad niedyrektywnego stylu pracy. W refleksjach dzieci pojawiła się też nuta krytyczna. Niezwykłe zespolenie pokonującej wszelkie trudności gromadki, gwarantujące trwałość i siłę wspólnoty, wydało im się zbyt fantastyczne, kiedy porównały fikcję literacką z rzeczywistością. Zestawienie w dyskursie tego aspektu życia wspólnotowego z kontekstem, w jakim przyszło żyć współczesnym dzieciom, ujawniło ewidentną rozbieżność. Rzeczywistość cywilizacyjna, w której zanurzeni są dzisiejsi uczniowie, nie sprzyja wspólnocie: ludzie są wobec siebie coraz bardziej podejrzliwi i tylko nieliczni są gotowi pospieszyć innym z pomocą; powszechne stają się próby wykorzystania swojej przewagi. Dyskurs, który się toczył wokół problematyki Pamiętnika Blumki, ujawnił więc nieoczekiwane pokłady złożonej wiedzy, nieschematycznego myślenia, w którym znalazło się miejsce dla marzeń o idealnej i rzeczywistej wspólnocie. 
W tej diagnozie jest wyraźna sugestia, że szkoła powinna konstruktywnie i wyprzedzająco wyartykułować swoją rolę w rzeczywistości teraźniejszej i przyszłej. Sprawą największej wagi jest bowiem stworzenie przestrzeni do poszanowania dziecięcego prawa do myślenia. Jak dowodzi Dorota Klus-Stańska: „realizowany w polskiej szkole model kształcenia i panujące w niej przekonania odnoszące się do tego, kim jest dziecko, jakie są jego możliwości rozwojowe, koncepcyjne i decyzyjne, powodują, że dzieci zostają pozbawione prawa nie tylko do wyrażania swoich myśli, ale również prawa do doświadczania takich intencjonalnie tworzonych warunków rozwojowych, które stymulowałyby to myślenie, pozwalały odnosić je do ważnych aspektów życia, rozumienia i działania" (Klus-Stańska 2010: 245).

W poszukiwaniu środków zaradczych dla współczesnej szkoły myślenie o dyskursie edukacyjnym warto zogniskować wokół Korczakowskiej pedagogiki wzajemności, która w wymiarze praktycznym przekłada się na otwartość na „momenty wychowawcze”. Sprzyja ona bowiem emancypacji przez wyzwolenie się od nacisków, unifikacji, programowania, hegemonii schematów. Sprzeciwia się uporczywemu podtrzymywaniu modelu edukacji transmisyjnej, nieprzystającego do potrzeb, jakie zgłasza rzeczywistość. Podważa słuszność przekonań sprowadzających proces uczenia się do rejestrowania, utrwalania i odtwarzania gotowych prawd oraz skłania do stawiania pytań o warunki nauczania zmieniające bieg procesu dojrzewania dziecięcych zdolności poznawczych oraz o efektywność zewnętrznych stymulacji.

Otwartość wiąże się też z odrzuceniem koncepcji dzieciństwa jako okresu „ochronnego", z którego trzeba wyrugować wszystko, co trudne i przesycone powagą, co nie wiąże się z beztroską i wesołością. W tym odgrodzeniu szkolnego bytu dziecka od prawdy życia, jak dowodzi Korczak, jest sztuczność i pedagogiczne zakłamanie.

Otwartość to również zgoda na ryzyko, że dziecko nie przyjmie proponowanej mu interpretacji świata, że poszukując własnych dróg rozwoju, pozna, czym jest wolność. Dyskurs dziecięcy potrzebuje atmosfery wolności, traktowania wolności jako szansy (Czerepaniak-Walczak 1996; Tchorzewski (red.) 1999; Schoenebeck 1999). To także przyznanie mu prawa do budowania tożsamości wolnego od narzucanych ograniczeń.

Istotą edukacji są więc dzielenie się wiedzą i pomysłami, wzajemna pomoc w konstruowaniu znaczeń, podział pracy i zamiana ról oraz nawiązanie relacji dialogowych i empatyczne otwarcie się na dyskurs dziecięcy. Włączenie dziecięcego punktu widzenia do dyskursu, który tworzy się w szkole, pomoże dziecku ten świat rozumieć, a także znajdować w nim własne ścieżki i budować samoświadomość. Można mieć nadzieję, że zainspiruje zmianę myślenia o wielowymiarowym i wieloaspektowym dziecięcym procesie objaśniania świata, bowiem - jak mawiał Korczak - z życia wzięte, łapane na gorącym uczynku, dające się zauważyć u bardzo małych dzieci objawy intelektualne słabną niećwiczone, zaniechane, niedocenione. U nielicznych dzieci mogą przetrwać w postaci ,zahibernowanej”, jednak z reguły można mówić o zaniku, przejściu w stan obcości, zapomnienia, całkowitego wyparcia ze świadomości. Zbyt późno pobudzone kontekstem, zadaniem - nie pojawią się na horyzoncie domysłów, poszukiwań czy hipotez interpretacyjnych. 


\section{Literatura}

Angrosino M. (2010), Badania etnograficzne i obserwacyjne. Tłum. M. Brzozowska-Brywczyńska, W. Kubiński. Kraków, PWN.

Bruner J.S. (2006), Kultura edukacji. Kraków, Universitas.

Czerepaniak-Walczak M. (1996), Wolność w wychowaniu jako przedmiot zawodowej refleksji nauczyciela-wychowawcy. „Rocznik Pedagogiczny”, 19.

Hołówka T. (1986), Myślenie potoczne. Heterogeniczność zdrowego rozsądku. Warszawa, PIW.

Klus-Stańska D. (2010), Prawo dzieci do myślenia - obszar w szkole nieznany, ,Szkice Humanistyczne", 10(2-3).

Kłakówna Z.A. (2003), Przymus i wolność. Projektowanie procesu kształcenia kulturowej kompetencji. Kraków, Wydawnictwo Edukacyjne.

Korczak J. (2012), Jak kochać dziecko. Dziecko w rodzinie. Warszawa, Proprint.

Korczak J. (2017), Momenty wychowawcze. Warszawa, Wydawnictwo Dragon.

Maćkiewicz J. (2000), Potoczne w naukowym - niebezpieczeństwa i korzyści. W: A. Dąbrowska, J. Anusiewicz (red.), Język a kultura. T. 13. Wrocław, Wydawnictwo Uniwersytetu Wrocławskiego.

Piekarski J. (2017), Perspektywa uczestniczaca w badaniach empirycznych - zarys tematyczny. „Przegląd Badań Edukacyjnych”, 2.

Schoenebeck von H. (1999), Po tamtej stronie wychowania. Życie w wolności od psychicznej przemocy. Tłum. E. Pastuszek, W. Żłobicki. Kraków, Oficyna Wydawnicza „Impuls”.

Tchorzewski de A.M. (red.) (1999), Wolność jako wartość i problem edukacyjny. Bydgoszcz, Wers. 